\title{
Facilities along the Syrian Hajj Route in Southern Jordan with Special Reference to the Fort of Fassou'ah and Its Water System
}

\author{
Mansour Shqairat \\ Associate Professor, \\ Department of Archaeology and Tourism Guidance, \\ Petra College for Tourism and Archaeology, \\ AL-Hussein Bin Talal University, \\ P.O. Box 20 Ma'an, Jordan
}

Doi: 10.36941/mjss-2020-0023

\begin{abstract}
The Syrian Hajj (Pilgrimage) Road, which links Damascus with the holy cities of Medina and Mecca in Saudi Arabia, was a historical road supplying the most basic needs of the pilgrims during this long journey. Most important are the water control and storage systems facilities which are reflected as archaeological remains. This paper discusses the water supply installations associated with the Hajj route with special reference to the Ottoman fort of Fassou'ah as one of the Hajj stations in southern Jordan.
\end{abstract}

Keywords: Hajj Route, Southern Jordan, Water control Systems, Ottoman fort, Cisterns, and Wells.

\section{Introduction}

The Arabic word for water, $m a^{\prime}$, occurs sixty-three times in the Quran. Muslims need water for wudu, washing before prayer, normally five times a day (Shqiarat 2005; 2008). The Syrian Hajj road (alternatively known as Darb al-Hajj al-Shami) linking Damascus and Mecca (a journey of at least 40 days) followed a pre-Islamic trade route of great antiquity, extending back to the Nabataean and Roman periods (Petersen 2012). This route connected major trading cities like Medain Saleh (Saudi Arabia), Petra (Jordan), and Damascus (Syria) with southern Arabia. It was of particular importance in the Ummayad period (AD 661-750), when Damascus was the seat of the Caliphate, and it remained a major route of trade and pilgrimage throughout the medieval and modern periods. It corresponds roughly with the later Hejaz railway and was furnished with stations along the Hejaz railway. These stations played a major role in nourishing all aspects of life in the region. The construction of stations was totally integrated with the railway line and their importance was as great as the railway line itself (Fig. 1). Most of the stations (the forts mainly) were built long time before the construction of the railway line; to ensure stability and security for the Hajj caravan, and to protect the water installations at or nearby, and later to provide comfort for all trains passing by the stations. These stations were more like forts to Ottoman army soldiers; thus they were symbols of power, i.e. they served as bases for military attacks carried out against rebellions. It served as a defensive frontier for the hajj stations, and later the railway line, against Bedouin raids in the south. 


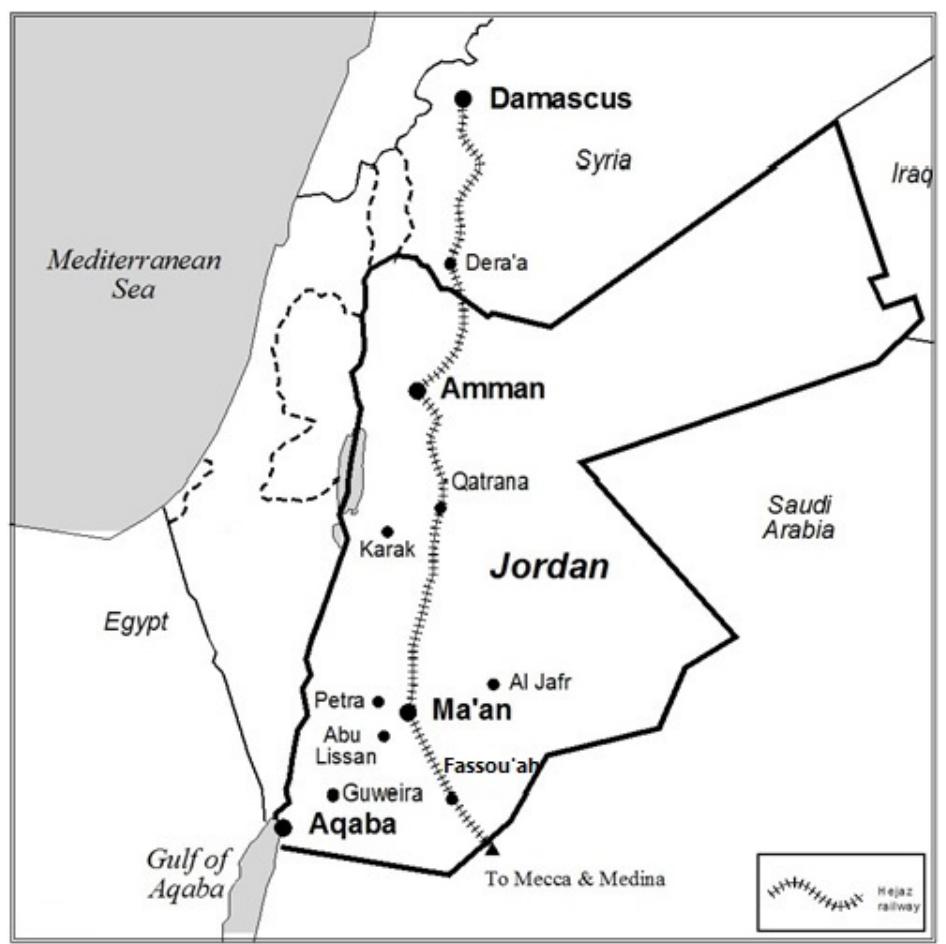

Figure 1: The Hejaz railway and location of Fassou'ah fort.

During Hajj season the Bedouins from the vicinity of the stations came to offer their products to pilgrims. The products usually included traditional medicines, foodstuffs, tobacco, coffee, sheep and goat meat, and water containers; they also bought products from Syrian and Turkish pilgrims. So the stations acted as local market to them. We suspect that human activity on the Hajj routes involved gathering, movement, accommodation, supply, social interactions, economic links,. In general, these stations contained living and lodge rooms, health units as sick bays, storage rooms, water wells, cisterns, and maintenance workshop trailers locations. In Jordan a series of these stations extends from Mafraq near the Syrian-Jordanian border in the northeast to al-Mudawrah on the border between Jordan and Saudi Arabia in the south. These include Mafraq, Al-Jeeza, Khan Al-Zabbeeb, Qatranah, Al-Hisa and Jurf Al-Darweish, Unaizah, Ma'an, Fassu'ah, Zat Hajj and al-Mudawarah (Petersen et al. 2003, Petersen 1991, Dmour 2003, Al-Salameen 2010, Bujard 1997). Early Islamic structures have been found at a number of sites along this route, and the range of objects is comparable to that found at Al-Rabadah (Darb Zubayda', Saudi Arabia) (Al-Rashidi986: 53-84; 1979; 1980; 2011). The use of this route in the Ayyubid and Mamluk periods is attested in Ibn Battuta's fourteenth-century pilgrimage itinerary (Petersen 1989: 107; 1994: 53; 1991); by the recorded attempt of Mamluk Sultan Barsbay (1422-1438) to prevent merchants from travelling with the Syrian caravan (Ankawi 1974: 150); and by the existence of several Mamluk forts on the route, such as those at Jiza and Zerka (Petersen 1994: 53; 1989; 1991). In fact, the Mamluk period (c. 1250-1517) witnessed a boom

${ }^{1}$ Darb Zubayda is the Hajj rout connecting Kufa in Iraq with the holly city of Mecca. It was named after Zubayda, the wife of the $5^{\text {th }}$ Abbasid caliph Harun Al-Rashid (ruled 786-809 AD) for her charitable works on the numerous stations along the trail, provided it with all necessary amenities like water reservoirs, wells, palaces and rest houses all along the road. 
in commerce and prosperity indicated by huge proliferation of markets in cities, villages, and on the Hajj routes (Al-Hamawi 1979: 163).This was a result of the official encouragement gave to merchants by the Mamluk sultans (Al-Qalqashandi 1978: 34). In turn the Mamluks gained substantial revenues from commercial taxes (Ibn Shaheen 1984: 132).

In the Ottoman period, the route continued, and its importance was reflected in the provision of new facilities like cisterns and the construction of a series of small forts (Petersen 1989; 1995). Historical chronicles confirm that the Syrian Pilgrimage Route formed the backbone of Transjordanian commerce during the Islamic periods. This route began in Damascus and proceeded via al-Kiswah, al-Sanamayn, Bosra, Ramtha, Mafraq, Dhlail, Zarqa, Zizia, Lejjun, Unayza, Ma'an, 'Aqabat Hejaz, Zat Hajj, Tabuk, al-'Ula, and al-Mdinah to Mecca (Petersen1995; 1991; Bani Younes 1997).

In $19^{\text {th }}$ century the Syrian Hajj caravan used to assemble at a great campsite at Muzeyrib, two days' journey from Damascus, and then move as one caravan toward Mecca. According to both John Burckhardt, writing in the early nineteenth century (1822: 240-242), and Charles Doughty, writing in the late nineteenth century (1956: 2-7), the caravan might be encamped for ten days, collecting stragglers, obtaining supplies, and paying the accustomed tribute to various tribes through whose territory the caravan was to pass. For much of the route, there was no actual road. According to Canon Tristam (1874), in 1872 the way was seldom more than a deeply worn, unpaved track that sprawled over a wide area.

Charles Doughty accompanied a Hajj caravan from Damascus to Medain Saleh in 1876:

There go commonly three or four camels abreast and seldom five; the length of the slow-footed multitude of men and cattle is near two miles, and the width some hundred yards in the open plains. The Hajjaj were this year by their account (which may be above the truth) 6,ooo persons; of these more than half are serving men on foot, and 10,0oo of all kinds of cattle, the most camels, then mules, hackneys, asses and a few dromedaries of Arabians returning in security of the great convoy to their own district (Doughty1956: 7-10).

Security was a key consideration, reflected in the layout and defense of the nightly camps. Doughty also reported that: small military tents of the Haj escort of troopers and armed dromedary riders, Ageyl (the most Nejd men), are pitched round about the great caravan encampment, at 60 and 6o paces: in each tent fellowship the watches are kept till the day dawning. A paper lantern after sunset is hung before everyone to burn all night, where a sentinel stands with his musket, and they suffer none to pass their lines unchallenged (Doughty 1956:10-11).

Before the completion of the Hejaz Railway between Damascus and Medina in 1908, the Hajj could be a grueling ordeal of up to two months' duration. Because the Muslim calendar is lunar, the timing of the feast of al-Adha, when the Hajj takes place, varies from year to year. Pilgrims might face freezing temperatures and torrential rains in winter or scorching desert heat in summer. Settlements were few, and the ponderous, well-supplied, and richly-equipped caravans were prime targets for tribal raiding parties. The Ottoman authorities also provided protection. A series of forts was constructed; the first in 1531, five more later in the century, and another three in the eighteenth century; by the eighteenth century, the raiders had become more dangerous through the acquisition of firearms (Kennedy and Petersen 2004: 13, Kennedy 1992).

The railway revolutionized the Syrian Hajj. By 1912, the Hejaz line was carrying 30,ooo pilgrims a year; by 1914, as word spread, the load soared to 300,000 (Babeli 2005: 55; Pearson1995). Here was a powerful fusion of modern industrial technology with traditional religious devotion. The railway was served by a total of 77 stations between Damascus and Medina, ranging from major stops at towns like Amman, Qatrana, and Ma'an, to desert halts like Aqabat-Hejaz, Batn al-Ghoul, and Wadi Rutm. These stations provided improved pilgrim facilities, many having, for example, large water cisterns. 


\section{Water for Pilgrims' Exploitation}

It is an obligation for all Muslims to fulfill the Hajj-the pilgrimage to Mecca-at least once in their lives, provided that they have the health and resources to do so. The expansion of the Muslim world from the mid-seventh century AD onwards meant that many traditional and often prehistoric routes gained increased and reconfigured significance from the regular passage of pilgrims. Consequently, three main Hajj routes developed: the Egyptian, bringing pilgrims from Egypt, North Africa, and subSaharan and West Africa (Petersen 1994; 2011); one bringing pilgrims from Iraq, Iran, and farther east; and the Syrian, bringing pilgrims from Syria and Anatolia. Because Hajj routes often passed through arid, inhospitable, under populated, and dangerous territory, Muslim states provided a range of facilities for pilgrims, including wells and cisterns, paved roads and bridges, markers and milestones, and khans and forts (Birks 1978; Tamari 1982). This has given rise to a distinctive medieval and modern archaeology of the Hajj routes (Petersen 1994, 2001; Shqiarat 2019b).

According to Gertrude Bell: "I asked him of the road to Mecca and of the hardships that the pilgrims endure upon the way, 'By the Face of God, they suffer,' said he. Yet it is not the pilgrims that suffer most, but those that keep the forts that guard the water tanks along the road" (Bell 1907: 73). It is clear that all the stations had water installations.

Water is also a concern in the desert of eastern Jordan, as it is elsewhere in Jordan, since there are limited water resources to support the country. The Bedouin have lived in the desert since preIslamic times. At present the Bedouin are less numerous and have different ways of life. In eastern Bayir (Jordan), the wells are the main water source. Other resources, such as what are known locally as Mushash, are still used sometimes by the Bedouin. Mushash are holes dug in the wadi sands or pebbles to find fresh water (Fig.2).

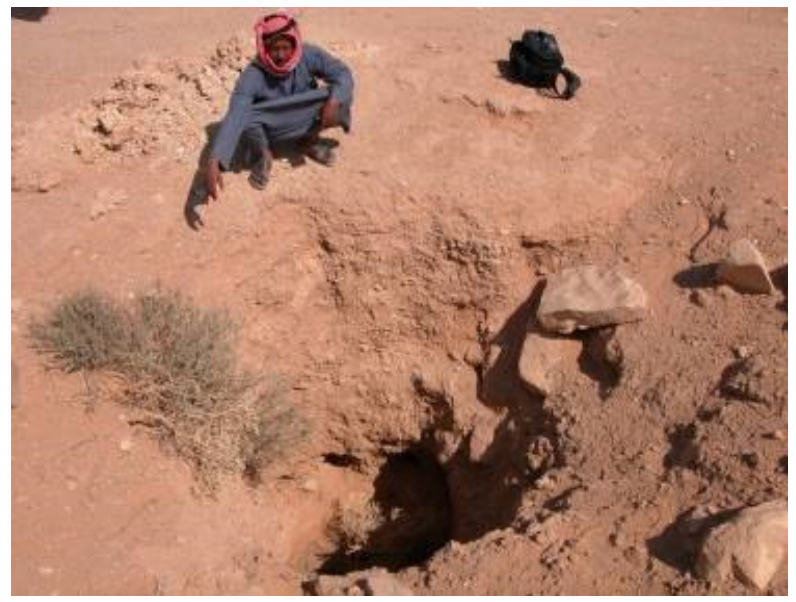

Figure 2: Recently dug Mushash at Mushash Fak Abu Ţaur to the east of wadi Bayir.

These can be seen in some wadis, especially in Wadi Fak Abu Ţaur. One can tell how familiar this system is from the names of some areas in the eastern desert, such as Mushash 'Hudruj, Mushash Um Zaqquha, and in northwestern Saudi Arabia, Mushash Dabil and Mushash Mudayyan (Tarawneh 2007). It appears that this system has been in use since at least the early Islamic period. It is clearly described by Al-Maqdissi in his journey which he finished in the year AD 985. He reported this method of obtaining water after his description of 'Aqaba (Ailah) but before he mentioned Bayir and its wells (Al-Maqddasi 1967: 250, 253). This method was also used in the Negev desert by Bedouin (Levy and Alon 1987: 59). This way of obtaining water in the barren desert of eastern Jordan and 
northwestern Saudi Arabia clearly confirms that the wadis acted as a point of attraction for wild animals and for humans with their flocks. As the arteries of life in the desert, they provided pasture for flocks and fresh water to drink and also attracted wild game to hunt.

Other sources of water in the desert were the isolated water pools in the wadis or Ghudran. These played a major role in attracting the pastoral Bedouin to specific areas, particularly if pastures were located in the surrounding areas. Some Ghudran in the eastern Bayir area still hold their place and names in the minds of Bedouin like Ghadeir Abu Turaifiat, Ghadeir Mu'ad, and Ghadeiral-Abyad. The rainfall in the desert and its effect on the Bedouin, particularly in northwestern Arabia, was described by Musil:

"As soon as Canopus appears, the Bedouins leave their camps, pitched in the valleys and the broad dried-up river beds, which are often over two hundred kilometres long. After copious rains have fallen at the heads of these valleys, the water rushes wildly through the channels, washing away the camps and drowning both the people and their herds; hence the proverb: "When Canopus rises, trust not the creek and gather dates even at night"... if the wasm aț-trûwi, the rain of the Pleiades, is likewise abundant, the grasses attain their full growth and the camels pasture on fresh 'ešeb (grass) even before the winter, aš-šta, sets in." (Musil 1928: 8).

Water is very important during the time of Hajj, as the site Mecca is located in the Hijaz. Therefore, the Hajj routes are divided into 2 groups: those passing through the ways close to wells and cisterns and those passing through the ways close to dams and qanats (subterranean channels). Wells are natural water resources containing groundwater and rainwater. Cisterns (birka in Arabic) are artificial reservoirs storing rainwater or water from other sources. During the Holy pilgrimage, stoppages are very common near cisterns or wells (Petersen 1994, 2008a, 2008b).

When going on pilgrimage, the local residents of Petra and the vicinity still transport water in a skin bag (known as a Qrbeh in Arabic). They claim that this is a Nabataean legacy; this seems plausible since the Nabataeans were famous for caravan routes across the desert through which they controlled long-distance trade. The Nabataeans also were famous for their skill in obtaining water in even the most arid environments. Water skins would thus have been an obvious and appropriate technology; the use of water skins probably dates much further back than the Nabateans. However, so far no archaeologically-established survival of a Nabataean water bag has been recorded; this is also not likely as leather is a perishable material. The Bedouins still use them to this day (Shqiarat 2019, 2005; Shqiarat et al. 2011, 2010; Al-Shqiarat 2018). At Fassou'ah fort we found modern water flasks (Rawaia) that had been carried on the backs of animals to the station (Fig. 3) (Shqiarat 2018; 2019a).

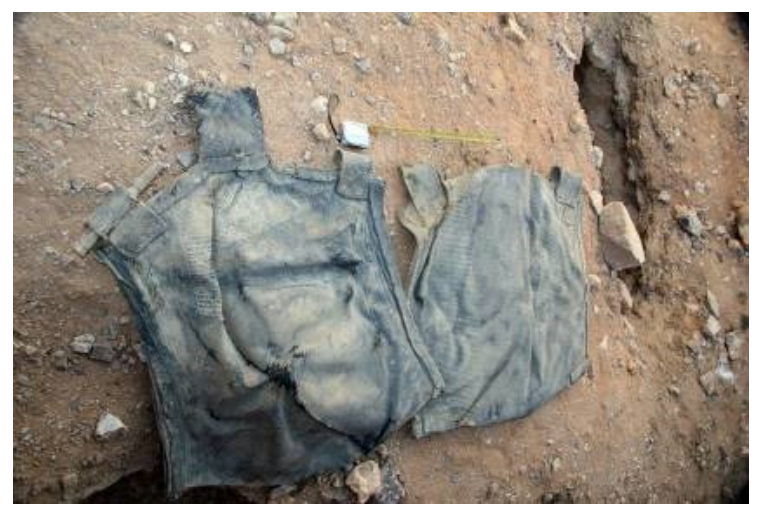

Figure 3: Water flasks "rawaia" carried on pack animals were used in Jordan until the early 1980s and were left inside the fort. 


\section{Water Storage along the Pilgrim Routes}

The hajj rout and the railway has left a strong archaeological imprint on the landscape, with its embankment, cuttings, bridges, culverts, cisterns, water towers, station buildings, and numerous railway engineering artifacts. However, there is often evidence for the earlier, pre-railway Hajj route. Petersen (1994) has listed the main types of installations recorded archaeologically: water systems, khans, mosques, forts, palaces, cemeteries, settlements, and roads. But he has also highlighted the limitations of the evidence so far collected.

Evidence from archaeological surveys between Damascus and Anatolia indicates the presence of caravanserais (khans) constructed during the sixteenth century in the northern Syrian Hajj routes (Petersen 1994; Sauvaget 1937). These caravanserais included large complexes which contained shops, a bathroom, and a mosque. These khans were present only in the northern parts of the Damascus route (Petersen 1994).

Mamluk constructed caravanserais, stopping stations, and hydrological installations in addition to modifying and improving some of the roads (Ibn al-Atheer 452). The Mamluk era (AD 1250-1516) witnessed major efforts to provide safety and facilities to the caravans passing through this route. The major period of fort construction along the Syrian Pilgrimage Route, however, was under the Ottomans (Petersen 1994:53; 1995). The Ottoman legacy of forts in Jordan began when Süleyman I became sultan in 1520 and expanded Ottoman authority over vast areas that had not been unified under one ruler since the early Islamic period. Süleyman regarded it as his duty to ensure that, each year, the Hajj caravan traveled from Damascus to Mecca and returned again safely. He employed three measures to achieve this goal: an armed, mounted escort (cerde), payments to local tribes (sürre), and the construction of forts (Al-Salameen 2010).

The garrisoned forts were built to achieve more security in the area and to stop the Bedouin raids against the caravans. Additionally, the Ottoman Empire wanted to encourage nomads wandering in the waterless desert to settle and to hold seasonal markets near this route, which would increase their income and would reduce their raids against the pilgrimage caravans.

Historical records confirm that there were conflicts between the Ottoman Empire and the Bedouin tribes, especially during the seventeenth and eighteenth centuries, and that these conflicts happened because the tribes raided and pillaged many pilgrimage caravans (Bani Younes 1997; Petersen 1991). The Ottoman sultans were eager to protect the caravans from the Bedouin raids and therefore adopted several protective and defensive procedures; this is represented in the extensive and intensive fortification along the Syrian Pilgrimage Route. The Ottomans also hired the sheikhs of locally dominant tribes in an effort to win over rebellious Bedouins (Walker 1999:214). This is indicated in the fortified castles built by Sulayman the Magnificent (1494-1566) at Qatrana, Ma'an, Dhat Pilgrimage, and Tabuk (Schick 1997-1998:570-571). Unayza castle in southern Jordan was built during the reign of the Ottoman Sultan Suleiman Pasha I in 1570, and Hassa castle was built by the Sultan Mustafa III (1757-1773) (Jaussen and Savignac1914:34-35).

\section{Mosques}

Small mosques on the Hajj routes were used by the leading members of the Hajj or the residents of that locality. It is documented by Petersen (1994) that the pilgrims would like to pray in the open air along with the Amir al-Hajj (in charge of Hajj caravan). An early example of a mosque on the Syrian Hajj route may be that outside the caravanserais at Khan al-Zebib (Creswell 1969: 505-6; Petersen 1994). We have noted two possible Mosques inside the fort in both levels.

\section{Cemeteries}

The number of deaths reported during the Hajj is very high. The possible reasons are (1) the age of pilgrims (who can afford the Hajj only after reaching middle age due to financial matters); and (2) the 
Hajj was a particularly difficult journey during which pilgrims were exposed to extreme weather conditions and distance. Al-Rashid(1986) and Petersen (1994) have reported that most of the graves are unmarked, although a few graves at al-Rabadah, a settlement in Saudi Arabia on the pilgrim rout from Kufa to Mecca, are marked with gravestones the name of the deceased. We have noted a reused cemetery near the Fassou'ah fort in southeast Jordan.

\section{Fassou'ah Fort in Southern Jordan as an Example}

Fassou'ah fort, which is known also as al-Mabrokah (Fig.4), is located approximately $54 \mathrm{~km}$ south of Ma'an $^{2}$. The area where the fort was built is called 'Aqabat Hejaz today and some Islamic travelers mention it as Aqabatas - Sawan. The fort is located at $1126 \mathrm{~m}$ above sea level ( $36 \mathrm{R}$ o778588, UTM 3296288) (Al-Salameen 2010) and was constructed at the bottom of a low valley which lies on the Darb al-Hajj al-Shami (Syrian Pilgrimage Route) 3 that was utilized by the yearly Syrian caravans coming from Damascus. We suggest that Fassoua'h may have been used as a khan because of the layout with cells around the courtyard. This suggestion is based on al-Rashid's (1978) conclusion that "It is possible that there were other, as yet unidentified khans on the Syrian Hajj route. By contrast, the Darb Zubayda contains numerous examples of buildings which may be interpreted as khans" (Petersen 1994: 51). And in our case we may see Fassou'ah as one of them.

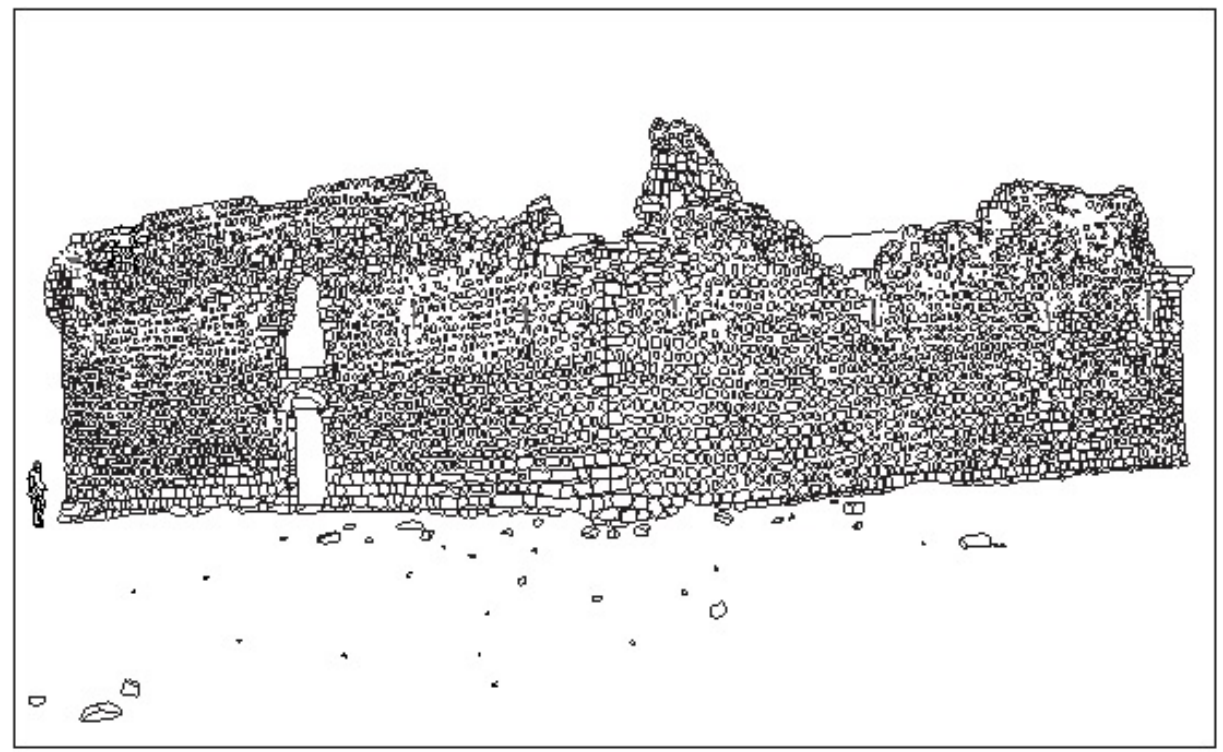

Figure 4: Three dimensional view for the fort from the northwest.

The history of the Fassou'ah fort is obscure although there are many traveler accounts which refer to the whole area. The fort has no founding inscription. Some of the inhabitants of the Ma'an governorate mention that there was an inscription resting on the entrance's lintel which said that the name of the fort is Saraya Kwaik, the local knowledge of the site's name and of the Ottoman sites in

${ }^{2}$ It took pilgrims 18 hours to reach this area from Maan station (al-Zayani 1967: 186).

${ }^{3}$ The origin of this route goes back to the beginning of the first millennium $B C$ when it was a major trade route linking Arabia with the Mediterranean. It flourished and prospered during the Nabataean period. During the Ottoman period, there were four main pilgrimage routes: one coming from Damascus and others coming from Egypt, Yemen, and Baghdad. 
general, is based on treasure hunting rather than on a personal or traditional knowledge., but unfortunately the inscription has disappeared.

The area of Aqabat Hejaz, where Fassou'ah fort is located, was mentioned by some Muslim historians and travelers who passed by this site. Ibn Battuta, in his Travels in Asia and Africa (13251354), says, "Thence we journeyed to Ma'an, which is the last town in Syria, and from 'Aqabat asSawan we entered the desert, of which the saying goes: He who enters it is lost, and he who leaves it is born. After a march of two days we halted at Dhat Hajj, where there are subterranean waterbeds but no habitations, and then went on to Wadi Baldah (in which there is no water) and to Tabuk, which is the place to which the Prophet led an expedition" (Ibn Battuta 1929: 153).

Other Islamic historians and travelers also refer to the area where the fort was constructed but do not refer the fort itself. Al-Khiyari al-Madani (1669) mentions the caravan stations constructed along the Syrian Pilgrimage Route and refers to the area of Fassou'ah as Thahr al-'Aqabah (19791980:85). Abu al-Qasim al-Zayani (1734-1839) went on pilgrimage through the Syrian Pilgrimage Route and mentions 'Aqabat Hejaz also and gives more details about other stations (Al-Zayani 1967: 186). Additionally, Muhammad al-Hussainy al-Musawi (1659) went via this route and he refers to this area as 'Aqabat As-Swan (Aqabat Hejaz).

Finally, Abi Bakr al-Dimashqi (died 1690) mentions that the name of this area was Thahr al'Aqabah and that it had another name that was 'Abadan; he describes this as a waterless area (2006: 248).

The fort and the nearby train station are connected with an important historical event contemporary to the wars of the Great Arab Revolt (during World War I). The importance of this area for the Arabian forces is attributed to several factors: there was a large Ottoman force in the fort and the station had a strategic location as well as the availability of water resources (Majali 2003:230-237). This area, however, witnessed the first failure of the Arabian forces of the revolt; Arabs decided to attack this area, but rumors associated with the Sykes-Picot Agreement in AD 1917 make them frustrated and discouraged to accomplish the attack (Majali 2003:230). Later, in early April 1918, Jafar al-Askari launched a military campaign departed from Abu Lassan, but due to storms and heavy rains the mission failed, and the Arabian forces returned to their main position at Abu Lassan.

Architecturally, the fort is a square structure measuring approximately $21 \mathrm{~m}$ per side with an entrance made in the middle of the northern side. The building materials include roughly dressed and unhewn stones whose size and dressing vary. White mortar was used as a joining white mortar was used between the stones. These stones were taken from a quarry which is located southwest of the fort.

The doorway is simple and consists of a large lintel resting on an entrance that is $1.4 \mathrm{~m}$ wide. This doorway seems to have been bolted with a wooden bar whose traces are still in situ. This leads into a long barrel-vaulted chamber which opens onto an open courtyard. In the middle of the courtyard there is a well.

The interior of the fort consists of two stories. On the ground floor in west of the courtyard, there are long barrel-vaulted chambers used probably as stables (fig.6) for bedding and feeding the animals. Other chambers might serve as storage rooms as they are not furnished with windows or wind openings, unlike the rooms of the first floor which have either a slit window or a window that opens onto the central courtyard.

Some of the Ottoman archives preserved at Topkapi Saray of palace and dated to the reign of Suleiman Pasha al-'Adhm (1733-1741) mention the items that were normally present in these forts and used by caravans, such as food (including barley and rice) as well as weapons (Sawaryyah and Tarawneh 2002:145).

The stairs leading to the first floor run up through the eastern and western sides of the courtyard. This floor was clearly used for defense and some of the rooms have strategic positions that give a clear view of the surrounding areas.

The first floor of the fort consists of rooms built in all directions except the southern side which contains a mosque built directly above the ground floor mosque. The first floor rooms were built with 
arrow or fire slits for defensive purposes, and these protected all the walls of the fort. The upper part of the fort has corner bartizans and one was constructed at the middle of the southern wall. Additionally, there is a water collection and storage system constructed north of the fort.

East of the courtyard there are semi-square chambers and to the south there is a mosque, whose Mihrab is decorated with stucco and fresco, although only traces could be observed. It seems that the mosque, which is incorporated into the design of the fort, was built to be used by people and garrisons stationed at this stop or passing by it. The two mosques indicate that they were designed for two classes of people: high-ranking officials and ordinary soldiers.

During the Ottoman period, this fort was used as a caravanserai and as a station to protect the pilgrims and to provide them with their needs. The basic function of such a structure is reflected in the sturdiness of the fort. The water installations which were constructed north of the fort were the main source that provided water to the whole area. After the construction of the Hejaz Railway, water available in these installations was used to replenish the trains in the nearby Aqabat Hejaz Station. There was a paved road that linked this fort with the Aqabat Hejaz Station; it was called DarbalBighal, "the Mules Route," since mules were the main means by which water was carried to the station. Robber pits inside the fort uncovered water skins which were used during the Ottoman period to carry water on mules through the Mules Route to the nearby railway station. There is a cemetery west of the fort. It seems that it was designed for the burial of pilgrims who passed away in this area and for deceased from the garrison.

On an architectural basis, we can assume that the origin of this fort was in the Ottoman period. Jaussen and Savignac suggested that this fort was built during the reign of the Ottoman Sultan Mustafa III (AD 1757-1773) (1909-1914:34-35).

The general plan of the fort might suggest earlier origins, and some architectural elements remind of Mamluk architecture. It should be mentioned that the Ottomans adopted some of the Mamluk architectural elements, and this is clearly apparent in Al-Hassa fort, which was built by the Ottoman Sultan Suleiman Pasha I in 1576 (Barbir 1980:135), (1909-1914:34-35) and the other forts of Unayza and Mudawwara from the same period. All these forts are very similar in terms of their general plans, walls, structures, and construction materials and techniques: they have a square structure with stables and storage chambers on the ground floor, accommodation for the garrison on the upper floor, and water reservoirs (Schick 1997-1998:571; Al-Salameen 2010).

Two inscriptions have been found in the main entrance of fort. The first one is a fragment of an undated early Islamic inscription. Paleographically, a date in the second and third centuries After Hijrah (AD 8th- $9^{\text {th }}$ centuries) seems most plausible for this inscription. Unfortunately the fragment is incomplete and broken, but the remaining part indicates that the writer of the inscription sought God's forgiveness. The second inscription is an Ottoman text written on the jamb of the main entrance, and it consists of three lines. It mentions names and signatures of pilgrims who came to the fort and who were looking forward to coming to this place (Al-Salameen 2010). Another piece of epigraphic evidence comes from the vicinity of the fort. North Arabian inscriptions are scattered in the vicinity of the fort which confirm that Bedouin tribes were wandering in this desert in the preIslamic periods (al-Ma'ani and Kareem 200o).

The fort was seemingly used in different periods because 'various layers of plaster were added to the internal walls of the structure indicate the fort was used and maintained for a prolonged period of time.

\section{Water Installations at Fassou'ah Fort}

Two rectangular pools (Birkah) have been recorded to the northwest of the fort (Figs. 5-6) at the conjunction of tow wadis. The pools and the fort were intentionally placed in this location in order to fill the pools (fig. 6). They are separated from each other by an area paved with undressed stones which acted as a catchment area and help to purify the running water of the wadis. Channels in this stone pavement directed the water into the pools. 
Two other apertures were also made in the northern pool in order to collect as much water as possible during the rainy seasons. Large openings were also noted near the northwest corner of the first pool (poolı fig.6) which collects more water because of its location near the wadis' conjunction (Fig. 5). In addition, a small basin was built near the northern wall of the northern pool which could have been used as a basin to water the animals (Fig.7). The western wall of the first pool (pool 1 fig.6) was intentionally curved in shape and wider than the northern and southern. we may interpret this as a way to smooth the running of the water to the pools and a way to strengthen the pool sides which face the running wadis' side.

The northern corners of the second pool (pool 2 fig.6) are supported by triangular buttresses. The other corners of both pools are supported by staircases which work like buttresses for them, since they are carefully designed and strongly built. These stairways and their location on the fort side of the pools may indicate that they were used often to fill Rawaia (the large flasks which were used to transfer water).

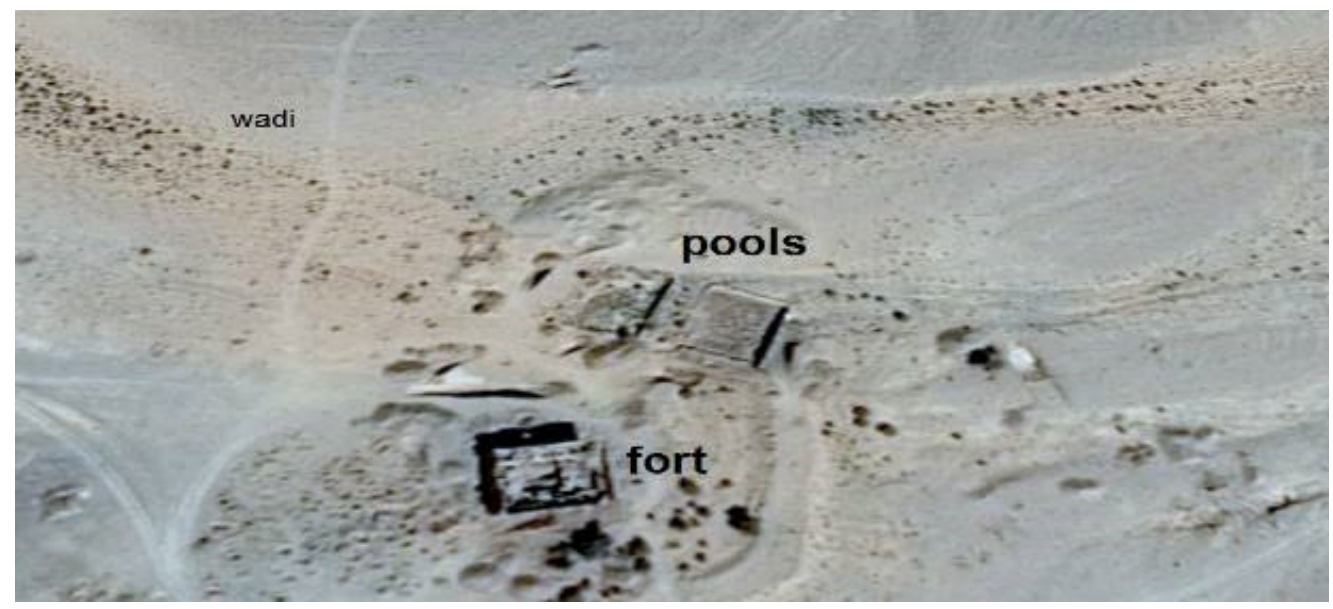

Figure 5: Google Earth photo showing the general layout of the site, the fort, and the main pools at Fassou'ah

Research indicates that several methods were used in the past for supplying water to similar installations. The standard arrangement was to build a deflecting wall across the wadi which would channel some of the flow into the cistern. The advantage of this system was that the reduced rate of flow would lower the amount of sediment flowing into the pool, thus easing maintenance. The amount of sediment was further reduced by placing the cisterns next to tributary wadis as opposed to the main channel. This type of arrangement reduces the possibility of damage during floods. Another technique was to have an inlet cistern in the middle of the wadi which fed the main cistern via a plaster-lined conduit. Petersen (1994) reported a few pools, smaller reservoirs in front of the main pools, which were probably used in water purification as settling tanks or filters. Petersen (1994) and Wilkinson (1980) argue that these tanks were used for feeding animals and such reservoirs were not required. 


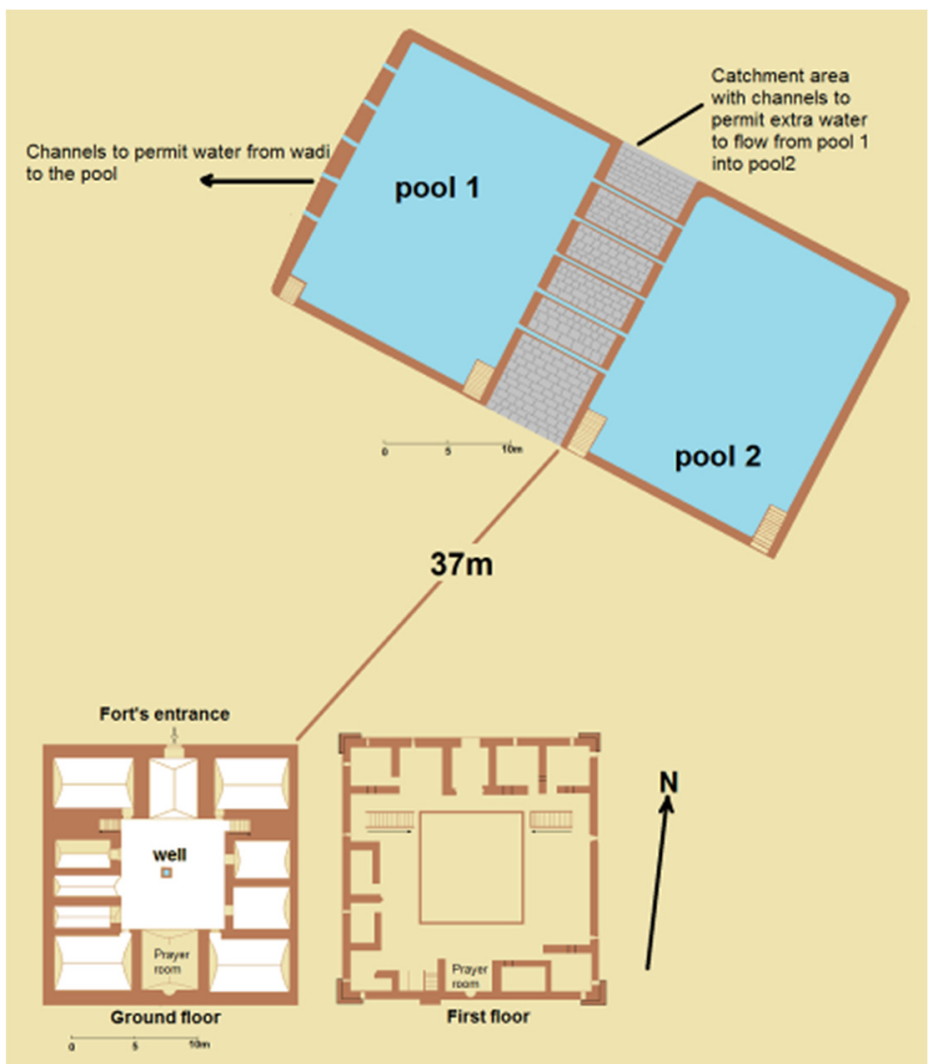

Figure 6: Top plan of the fort and the water system at Fassou'ah (created by Saad Twaissi based on Google Earth; Al-Rashdan 2011:149-151, figs. 4a-c; Petersen 2012:114, 122, figs. 36-37).

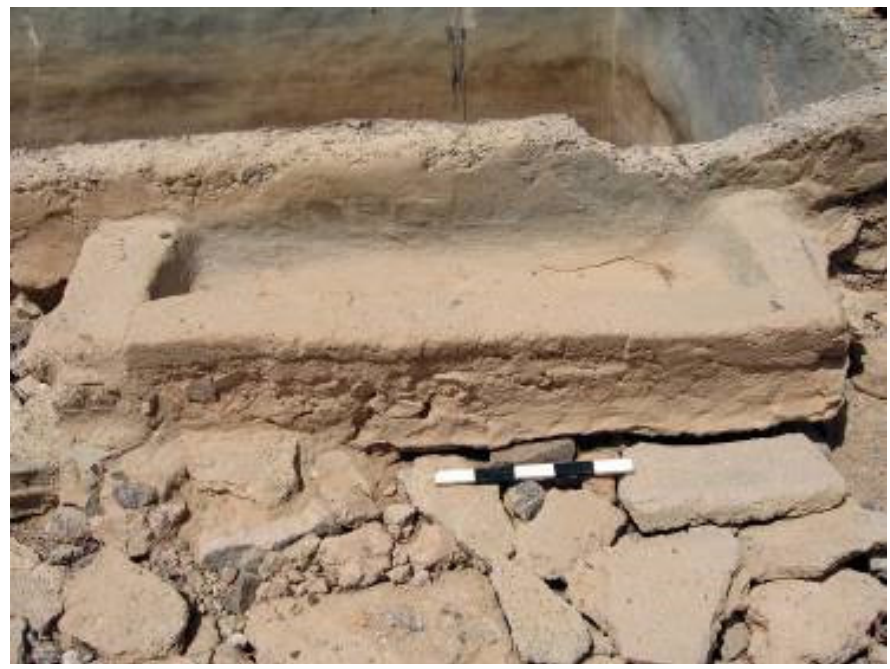

Figure 7:. Small water tank used for flocks of sheep, goats, and camels. 
A third pool (Fig. 8) is located 200 meters to the southeast of the fort. This pool is rectangular in shape and was built of cement which was covered to prevent evaporation and water pollution. This pool was repeatedly conserved and cracks were closed by using asphalt. In addition, and according to a Bedouin (modern Bedouin) who came with his camel around the fort. This can be seen from the small Mashrab or the basin which is normally used for animals. Stones were used to create a triangular area at the runnel side to collect water before it reaches the small channel which has a net of iron bars placed to function as a double filter. The channel ends with a small opening in the pool wall. This pool was placed in this location and far enough from the larger wadi in order to protect it from erosion because of its small size and thin-walled sides; at the same time, a small water runnel can fill it in a good rainy season.

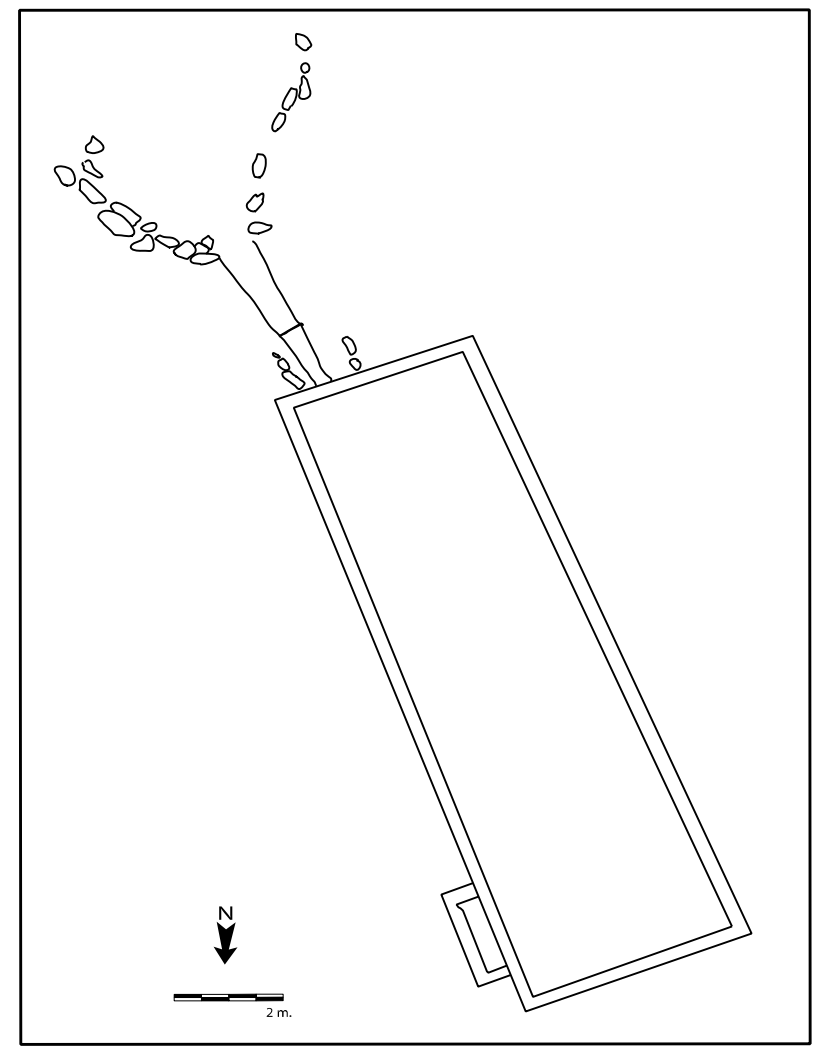

Figure 8: Reused water pool (cement) still in use by Bedouin to the southeast of the fort

\section{The water well}

A circular water well has been found inside the fort, its dimensions have not been explored yet because it is sealed by debris. It was used to collect water from the roof in winter. The roof of the fort was designed to direct water in one corner which was always toward the water well, and tabular iron Mizrabs were used to direct water near the roof edge (Figs. 6, 9). This water was purer than that in the two pools outside and could be used for cooking and drinking by those who lived inside the fort. Similar techniques have been in use in Jordanian peasants' villages since the Ottoman period or possibly earlier (Shqiarat 2018). 


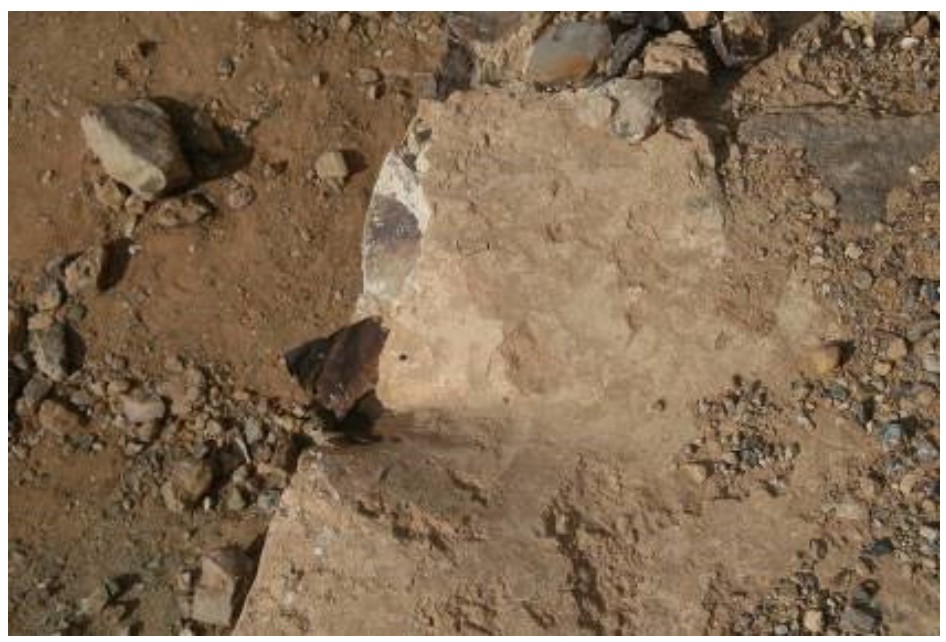

Figure 9: Mizrab used to collect roof water into a water well in the center of the fort.

\section{Conclusion}

The $1400+\mathrm{km}$ Hajj road between Damascus and the holy cities was an important historical road that served all Muslims from the eastern part of the Muslim world. Controlling this road and securing it was a symbol of the power of the Muslim caliphate. The most critical issues to be considered here are security and water. Thus through the 1400 years of Islamic history this road had been a subject of continuous process of improvements and refurbishing, by furnishing it with series of stations for security and logistic support, and water facilities, as natural water sources are not available along most of its trail. The most intensive work along the hajj road was during the Ottoman period indicated by intensive fortification and water collecting systems, the best example of which is the fort at Fassou'ah , in southern Jordan and its water collecting system. The systems indicate the best practice to harvest water in the most arid areas by building a deflecting wall across the wadi to channel the seasonal run-off and rare rainwater to the wadi into the cistern. The fort however, was to secure the water sources to ensure its availability during the hajj season. Further intensive archaeological work and excavation in this fort and other similar stations in southern Jordan is recommended to develop better understanding of the water harvesting systems in these most arid and remote areas.

\section{References}

'Ankawi , A. (1974) The pilgrimage to Mecca in Mamluk times.Pp. 116-70 in R.B. Serjeant and B.L. Bidwell (eds), Arabian Studies I. Hurst and Company: London.

Abi Bakr, al-Dimashqi. (2006). Jazeerat al-'Arab. Translated into Arabic from Turkish by Musa'd al-Shaman (In Arabic).

AI-Zayani, A.A. B.A. (1967) AI-Tarjumana AI-Kubra ed., 'Abd AI-Karim AI-Filali Metbat Fadhala, Morocco.

Al-Hamawi, S. D. Y. (1979). Mu'jam al-Buldan, Beirut, Dar Ihia' al-Turath. (In Arabic).

Al-Khayari al-Madani, Ibrahim. (1979-1980).Tuhfat al-'Udabawa-salwatal-Ghuraba. Ministry of Media. Cairo (In Arabic).

al-Ma'ani, S. and Kareem, J. (2001). Qiraah Linuqush Thamudiyah Jadydah mn 'Aqabat Hejaz. Al-Manarah 8:2: 4384 (In Arabic). 
Al-Maqddasi, S. (1967). Bibliotheca Geographorum Arabicorum: Describtio Imperii Moslemici. ed. De-Goeje, M. Lugduni Batavorum: E. J. Brill. (In Arabic).

Al-Musawi, Muhammad al-Hussayni (1385 AH). Rihlatal-Shitaa wal-Saif. Islamic publishing Centre, Beirut. (In Arabic).

Al-Qalqashandi, A. A. A.(1978). Subhal-A’sha fy Sina'atal-Insha, Lebanon, Dar al-Fiker (In Arabic).

al-Rashid, S. (1978) Darb Zubayda in the Abbasid period: Historical and archaeological aspects. Proceedings of the Seminar for Arabian Studies 8, 33-45.

al-Rashid, S. (1979). Darb Zubaydah Survey Project: Ancient Water-Tanks on the Haj Route from Iraq to Mecca and their Parallels in other Arab Countries. Atlal (3): 55-62.

al-Rashid, S. (1980) Darb Zubayda. The Pilgrim Road from Kufa to Mecca. Riyadh University Press: Riyadh.

al-Rashid, S. (1986) al-Rabadhah: Portrait of early Islamiccivilization in Saudi Arabia. King Saud University Press: Riyadh.

al-Rashid, S. and Young, M.J.L. (2011) Darb Zubayda. Encyclopaedia of Islam, 2nd edn, vol. 12, 198.

Al-Salameen, Z. (2010). The Archaeological Remains Discovered Near the Syrian Pilgrimage Route in the 'Aqabat Hejaz Region Southern Jordan. Journal of History and Archaeology of Jordan. Vol.4.Issue No.2:171 -203 (In Arabic).

Al-Shqiarat, M. (2018). Water Management in Jordan Past, Present and Future. Lambert Academic Publishing.

Al-Zayani, Abu al-Qasim. (1967). al-Turjumanah al-Kubra fy akhbr al-ma'murah baran wabahran. Ministry of Information, Morocco. (In Arabic)

Babeli, M.(2005). 'The Hejaz Railway', in I-MAG Magazine, 4, May 2005: 31-33, www.i-mag.org.

Bani Younes, M (1997).Qafliat al-Hajj al-Shami fy Sharq al-Urdun fy al-'Ahd al-'Uthmani. Ministry of Culture, Amman. (In Arabic).

Baram, U. and Carroll, L. (eds.).( 200o). A Historical Archaeology of the Ottoman Empire: Breaking New Ground. New York: Kluwer /Plenum.

Barbir, K. (1980). Ottoman Rule in Damascus (1708-1758). Princeton University Press, Princeton.

Bell, G. (1907). The Desert and the Sown (William Heinemann Ltd, London).

Birks, J. S. (1978). Across the Savannahs to Mecca: the overland pilgrimage route from West Africa, London, Frank Cass.

Buchli, V. and Lucas, G. (eds).( 2001). Archaeologies of the Contemporary Past, Pp3-18. London: Routledge.

Bujard, J. (1997) Umm al-Walîd et Khân az-Zabîb, cinq qusûr omeyyades et leur mosquées revisités. Annual of the Department of Antiquities of Jordan 41, 351-74.

Burckhardt, J.L. (1822) Travels in Syria and the Holy Land. John Murray: London (reprinted 1983 AMS Press New York).

Creswell, K.A.C. (1969) Early Muslim Architecture: Umayyads, Early Abbasids and Tulunids. 2 vols. (3 Parts). Oxford University Press: Oxford.

Dmour, H. (2003). Hejaz Railway Stations in the Middle and South Jordan: Architectural study. (In Arabic). Unpublished MA Thesis. Yarmouk University, Jordan.

Doughty, C. (1921). Passages from Arabia Deserta, Jonathan cape. London.

Doughty, C. (1956). Passages from Arabia Deserta, Harmonds worth, Penguin.

Ibn al-Atheer (2003). al-Khamel fy al-Tarick . Dar al-Kutub al-'Ilmiyyah.(In Arabic).

Ibn Battuta (1929). Travels in Asia and Africa 1325-1354, tr. and ed. H. A. R. Gibb, London: Broadway House.

Ibn Shaheen, G. D. (1984). Kitab Zubdat Kashfal-Mamalekwa Bayan al-Turq walmasalek, Paris: Al-Matba'ah alJumhuriyah (In Arabic).

Jaussen, A. and Savignac, R. (1909-14). Mission Archéologique en Arabie. Libraire Orientaliste Paul Geuthner, Paris. Kennedy, D. (1992) The Roman frontiers in Arabia (Jordanian Sector). Journal of Roman Archaeology 5, 473-89.

Kennedy, D. and Petersen, A.D. (2004) Guardians of the Pilgrims Wells; Damascus to 'Aqaba. Saudi Aramco World 55 No. 1, 12-19.

Levy, T. and Alon, D. (1987). Settlement Patterns along the Nahal Beer Sheva- Lower Nahal Besor: Models of Subsistence in the Northern Negev. In Shiqmim I, Studies Concerning Chalcolithic Societies in the Northern Negev Desert, Israel (1982-1984). 1: 45-138. ed. Levy, T. BAR International Series 356. Oxford: B.A.R.

Majali, B. (2003). Al-Masarat al-'Askariah le lthawrah al'arabiah alkubra. Al-Hussein Bin Talal University, Ma'an. (In Arabic).

Musil, A. (1928). The Manners and Customs of the Rwala Bedouins. New York: Czech Academy of Sciences and Arts.

Petersen, A. (1989). Early Ottoman Forts on the Darb Al- Hajj, Levant, Vol. 21: 97-117.

Petersen, A. (1994). 'The archaeology of the Syrian and Iraqi Hajj routes'. World Archaeology, Vol. 26 (1): 47-56. 
Petersen, A. (2012). "Catalogue of Hajj Forts in Jordan”, in Petersen, A. with contributions by Dibol; Genequand, D. Grey, T. Simbson, J. and Tutuncu, M. The Medieval and Ottoman Hajj Route in Jordan and Syria: An Archaeological and Historical Study, Levant Supplementary Series vol.12,Oxbow Books: Oxford, Pp. 57-129.

Petersen, A.D. (1989) Early Ottoman Forts on the Darb al-Hajj. Levant 21, 97-118.

Petersen, A.D. (1991) Two forts on the Medieval Hajj route in Jordan. ADAJ 35, 347-59.

Petersen, A.D. (1994) The archaeology of the Syrian and Iraqi Hajj routes. World Archaeology, 47-56.

Petersen, A.D. (1995) The fortifications of the Pilgrimage Route during the first three centuries of Ottoman Rule (1516-1757). Pp. 299-305 in K. 'Amr, F. Zayadine and M. Zaghoul (eds), Studies in the Archaeology and History of Jordan, vol. 5. Department of Antiquities: Amman.

Petersen, A.D. (2001) Ottoman Hajj Forts. Pp. 685-91 in B. MacDonald, R. Adams and P. Bienkowski (eds), The Archaeology of Jordan. Sheffield Academic Press: Sheffield.

Petersen, A.D. (20o8a) The Medieval Hajj Route Through Syria and Jordan. In K.D'Hustler and A. van Tongerloo (eds),Festschrift Professor Urban Vermeulen; Fatimid, Ayyubid and Mamluk Studies. Peeters: Leuven.

Petersen, A.D. (20o8b) The Ottoman Hajj route in Jordan: motivation and ideology. Pp. 31-50 in Bulletin d'études orientales Supplément 57 (March), Le pouvoir lâge des sultanats dans le Bilad al-Sham. Proceedings of a seminar held at IFPO-ACOR, Amman, 15-16 mai 2005.

Petersen, A.D., Brun, P. and Shurma, A. (2003) Excavations and Survey at Qal'at 'Unaiza in Jordan. Levant 35.

Rashdan, W. and Sha'aban, T.(2011). An Ottoman Foundation Inscription in the Ottoman Fort of Ma'an, Jordan. (in Arabic). Journal of History and Archaeology of Jordan, vol.5.Issu 1:117-1140.

Saidel, B. A.( 2001). 'Abandoned tent camps in Southern Jordan', in Near Eastern Archaeology, Vol. 64 (3): $150-157$.

Sauvaget, J. (1937) Les caravanserais Syriens du Hadjdj de Constantinople. Ars Islamica 4, 98-121.

Sawaryyah, N. and Tarawneh, M. (2002). Mintaqat al-Karak wal-Shounakk hilal al-fatrah 934 AH /1527 AD -1023 A H /1625 AD. Dirasat,29,1: 141-156 (In Arabic).

Schick, R. (1997-1998).The Archaeology of Palestine / Jordan in the Early Ottoman Period. Aram 9-10: 563-575.

Shqairat, M. Abudanh, F. Twaissi, S. (2010).Water Management and Rock-Cut Cisterns with Special Reference to the Region of Udhruh in Southern Jordan. Journal of History and Archaeology of Jordan.4.2: $205-227$.

Shqiarat, M (2019). History and Archaeology of Water Management in Jordan Throgh Ages. Scientific Culture, Vol. 5, No. 3, (2019), Pp. 41-54.

Shqiarat, M. (2019a). Greek, Hellenistic and Roman Byzantine Water Management Technology: Overview from Jordan. Open Access Journal of Archaeology and Anthropology.Voll.1-Is.2.Pp1-15.

Shqiarat, M. (2019b). Geology and Climate Relating to Archaeological Water Management in Jordan. Global Journal of Archaeology and Anthropology.Voll.9.Is.2.Pp.1-10.

Shqiarat, M. (2008). The Archaeology of Water Control in the Nabataean and Roman-Byzantine Periods in Jordan: Overview and Case Studies from Key Sites. Cura Aquarum in Jordanien. Siegburg :21-45.

Shqiarat, M. (2018). Abandoning Shammakh: Historical Archaeology among the Villages of Southern Jordan and its Ethno-Archaeological And Modern Economic Potential. Journal of Anthropology and Archaeology, Voll.6.1.Pp.1-18.

Shqiarat, M. (2018). Water Management in Petra: Nabataean Hydraulic Overview. Journal Management Science and Engineering.Voll.12.Is.3.Pp.12-23.

Shqiarat, M. Al-Salameen, Z. Faulkner, N. Saunders, N. (2011). Fire and Water: Tradition and Modernity in the Archaeology of Steam Locomotion in a Desert War. Levant. 43.1:98-113.

Tamari, S. ( 1982). Darb Al-Hajj in Sinai, Atti dell Accademia Nazionale deiLincei, S.VIII, XXV (4). Rome.

Tarawneh, M ( 2007) Pastoral Nomadism in the Southern Levant during the Chalcolithic Period: New Evidence from Eastern Bayir. PhD Thesis University of Sydney.

Tristam, H. B.(1874). The Land of Moab: travels and discoveries on the east side of the Dead Sea and the Jordan, London: John Murray.

Walker, B. (1999). Militarization and Nomadization: The Middle and Late Islamic Periods. Near Eastern Archaeology 62,4: 202-232.

Wilkinson, T. (1980). (Reprinted in 2001). Darb Zubayda Architectural Documentation Program: Darb Zubayda1979: The water resources. Atlal 3: 51-67. 